\title{
ВЗАИМОСВЯЗЬ МЕГАСДВИГОВЫХ ДИСЛОКАЦИЙ И РЕГИОНАЛЬНОЙ НЕФТЕГАЗОНОСТИ ЗАПАДНО-СИБИРСКОЙ ГЕОСИНЕКЛИЗЫ
}

Филиппович FO.B.

(Тюменский филиал ООО «КогальмНИПИнефть»)

В пределах Западной Сибири разрывные линеаменты трансрегионального масштаба традиционно выделялись по геоморфологическим признаками, результатам аэрокосмодешифрирования, интерпретации потенциальных полей и нашли свое отражение практически на всех известных и малоизвестных тектонических картах и схемах. Однако их горизонтально сдвиговая природа в явном виде стала широко рассматриваться лишь в последнее время [Натальин, Шенгёр (2000); Филиппович (2001); Подурушин (2003); Егоров, Чистяков (2003); Пучков (2003); Соборнов, Якубчук (2006)].

В качестве основных мегасдвитовыг дислокаций Западной Сибири по комплексу геологогеофизических параметров автором выделены правосторонний Тургайский и левосторонний СаяноПайхойский мегасдвиги, формирующие геометрически правильную диагональную систему.

Анализ площадного взаимоотношения установленной региональной нефтегазоносности ЗСГС и генерализованньг линий трансрегиональных сдвиговых дислокаций выявил следующие очень любопытные закономерности.

Во-первых, взаимосвязь с простиранием и морфологией нефтегазоносных структур. Так, Саяно-Пайхойский линеамент контролирует зону принципиального изменения простирания структурных элементов, которые приобретают северо-западную направленность. При этом в полосе непосредственного влияния северного фрагмента Тургайского мегасдвига сохраняется северо-восточная ориентировка структур (Мессояхский порог).

Во-вторых, перекрещивающиеся СаяноПайхойский и Тургайский мегасдвиги разделяют территорюю ЗСГС на четыре тектонических блокасектора, которые контролируют растределение региональных УВ-систем с различным фазовым составом и стратиграфической приуроченностью. Так, наиболее выраженная закономерность отмечается по южному и северному блокам. Первый - в основном нефтяной, второй - преимущественно газоконденсатный. При этом оба отличаются максимальным этажом нефтегазоносности. Восточный и западный блоки характеризуются смешанным составом месторождений УВ (нефтегазоконденсатные).

Такое закономерное площадное распределение нефтегазоносности позволяет сделать следующий основной вывод.

Саяно-Пайхойский и Тургайский метасдвиги каждый в отдельности разделяют ЗСГС на два смежных мегаблока с принципиально различным фазовым составом УВ-систем. Относительно СаяноПайхойского линеамента северо-восточный мегаблок контролирует область преимушественного газообразования, а юго-западный - с преобладаюшим нефтяным потенциапом.

Относительно Тургайского мегасдвига предполагается аналогичная закономерность: юго- восточный мегаблок отличается преобладающей генерацией УВ нефтяного ряда, а северо-западный, по крайней мере, значительным влиянием процессов газообразования.

Соответственно, в отмеченных выше северном и южном блоках-секторах, где набтюдается совпадение специфики формирования месторождений, сохраняется условно однофазный характер УВсистем: газовый в северном и нефтяной - в южном.

В восточном же и западном блоках-секторах, где происходит «наложение» контрастных генерационньх процессов, широкое развитие имеют смешанные УВ-системы. В качестве примеров месторождений восточного блока-сектора можно привести Верхне-Коликъеганское, Бахиловское, Харампурское, Тагринское, Етыпурское, Варьеганская группа, Вынгапуровско-Вынгаяхинская группа, Губкинская группа, Таркосалинская группа, Комсомольская группа и многие другие. Для западного сектора - это Карабашское, Иусское, Даниловское, Верхне-Кондинское, Восточно-Тугровское, Пальяновско-Емъеговское и частично Талинское нефтегазоконденсатные месторождения, а также, конечно, Шухтунгортская, Игримская и Березовская группы чисто газовых месторождений.

Выявленная региональная закономерность позволяет уверенно говорить об определяющем влиянии на характер нефтегазоносности ЗСГС тектоно-динамического фактора. Северный блок однозначно испытывает преобладающие процессы растяжения, южный - сжатия. Восточный и западный отлицаются более сложной тектонодинамической обстановкой. Причем, оба должны испытывать вращение вследствие трансрегиональных напряжений: восточный - по часовой стрелке, западный - против часовой стрелки. Здесь необходимо отметить, что направления вращения совпадают с установленными соответственно для Сибирской и Русской ппатформ.

Таким образом, возникающий в тектонически мобильных зонах термомеханический стресс, механохимическая активизания, неравномерное распределение по площади и разрезу термодинамических характеристик обуславливают направленность и стиль процессов регионального и зонального нефтегазообразования и нефтегазонакопления. Соответственно, в свете рассматриваемой концепции представляется, что выявленные трансконтинентальные мегасдвиговые дислокации определяли специфику крупных зон нефтегазонакопления. 